\title{
Til Knud Ellitsgaard-Rasmussen
}

Kære Ellitsgaard

Senectus est natura loquacior (Cicero)

Som den længstlevende af GGUs første styrelse har jeg taget mig den frihed at opfatte mig selv som en slags bedstefar til den institution, du har bygget op. Som den gamle mand, jeg efterhånden også er, vil jeg ikke undlade ved denne lejlighed at berette lidt historie, der ellers nemt kan gå $\mathrm{i}$ glemmebogen.

Oldtiden: Under besættelsen drøftede vi geologer naturligvis ofte, hvad vi ville lave efter krigen, herunder de fristende og forpligtende opgaver, vi måtte prøve at løse i Grønland. Så længe jeg var ansat på DGU (1938-42), var det især med dr. Keld Milthers, jeg drøftede tingene, men efter min udnævnelse til professor og tilbagevenden til museet i 1942 blev det fortrinsvis docent ved DTH, Alfred Rosenkrantz, og mig, der udvekslede synspunkter. Rosenkrantz havde netop da to Nûgssuaqekspeditioner på bagen; men som sagerne stod, bevægede vi os jo på det abstrakte plan.

Ikke længe efter krigens oph $\varnothing$ r skete der imidlertid noget helt konkret, idet direktøren for Grønlands Styrelse, Knud Oldendow, ringede mig op og bad om en samtale. Den fandt sted den 19. juli 1945, fra kl. 10 til 11.15. Jeg erindrer ikke, om der blev taget referat af samtalen; efterfølgende st $\emptyset$ tter sig på optegnelser i min personlige, lapidariske dagbog. For en sikkerheds skyld må læseren nok have tilføjelsen 'såvidt jeg husker' med i tankerne.

Når jeg var alene om at repræsentere geologerne, beroede det på, at direktøren for DGU, dr. Hilmar Ødum, som under krigen havde set sig nødsaget til at flygte til Sverige, endnu en tid lang forblev der, samt at Rosenkrantz (nu professor ved DTH) befandt sig på vej til Grønland (Østgrønland).

Oldendow og jeg begyndte vor samtale med at drøfte formen for et kommende GGU. Vi forestillede os begge, at det fremtidige arbejde blev indledt $\mathrm{i}$ Vestgrønland. 'Med Grønlands Styrelse som knappen, det drejer sig om' (Oldendow).

Kryolitselskabet $\emptyset$ resund, der var positivt interesseret i sagen, 'kan ikke få nogensomhelst opgavestillende myndighed' (Oldendow).

'Lauge Koch er nu og i fremtiden "kalltgestellt" i Vestgrønland' (Oldendow).

'Det vil være nødvendigt, at vi går systematisk i gang med at oparbejde en videnskabelig (geologisk) reserve, som man kan trække på i fremtiden; man kan ikke indskrænke sig til at gå efter formodede "rosiner" i kagen. Første punkt i dette arbejde må være at tilvejebringe et geologisk kortmateriale. Ved siden af dette hovedarbejde kan man måske udstationere folk til samarbejde med geofysikere om helt konkrete opgaver' (Noe).

'Deres plan ligner i mange henseender Kochs, og det bestyrker mig i, at den er rigtig. Hvornår vil De kunne gå i gang?' (Oldendow).

'Vi vil kunne begynde i 1946 på fagligt fuldt betryggende måde med en række opgaver; men på ét felt står vi uden tradition her i landet: Grundfjeldet. De folk, der skal i gang med det, må have en supplerende uddannelse' (Noe).

Samtalen gik videre, og Oldendow gik over til at tale om nedsættelsen af et udvalg, som 


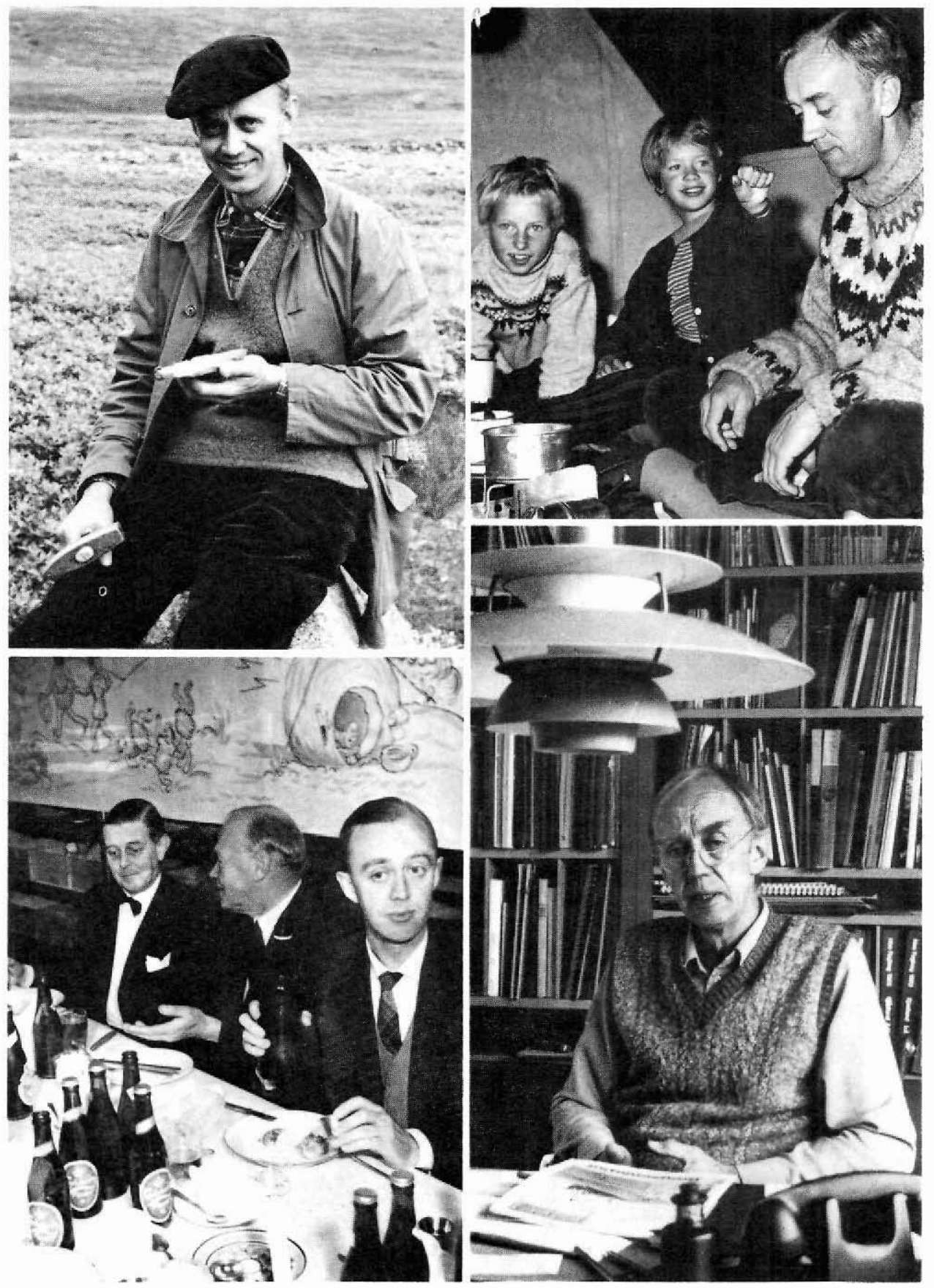

K. Ellitsgaard-Rasmussen in the field, in the office, and at 'lunch' with A. Noe-Nygaard and A. Rosenkrantz. 
han benævnte 'en sekstant'. Det var tænkt sammensat således: Arne Noe-Nygaard, Mineralogisk Museum, prof. N. E. Nørlund, direktør for Geodætisk Institut, direktør K. Oldendow, Grønlands Styrelse, direktør Helge Petersen, Meteorologisk Institut, prof. Alfred Rosenkrantz, DTH og direktør H. Ødum, DGU.

Senere samtaler mellem geologerne og de to institutledere, Nørlund og Petersen, viste temmelig hurtigt, at sekstanten som udgangspunkt ikke foreløbig var praktiserbar. Geologerne måtte først erhverve sig et fagligt ståsted, inden et samarbejde om konkrete opgaver kunne tage dets begyndelse.

Når direktør Oldendow forestillede sig et udvalg, der skulle omfatte alle geo-fagene, hang det naturligt sammen med de gode erfaringer, Grønlands Styrelse havde med hensyn til samarbejde med institutioner som Geodætisk Institut, der tog sig af den topografiske kortlægning, af gravimetrien og driften af den seismiske station i Scoresbysund, og med Meteorologisk Institut der på sin side tog sig af vejr- og istjenesten samt arbejdet på det magnetiske observatorium i Godhavn. Det var tydeligvis på en tilsvarende måde, at han forestillede sig et kommende GGU opbygget. Hvad økonomien angik, forestillede Oldendow sig, at den ville gå af sig selv, således at penge til lønninger og instrumentering etc. måtte forudses udredet af vore egne ministerier til hver af os, mens resten - f.eks. til køb af både - burde gives som bevilling til Grønlands Styrelse. Det var ganske klart Oldendows indstilling, at Grønlands Geologiske Undersøgelse måtte gennemføres støttet på danske institutioner. Han delte også synspunktet, at en kulturnation har en naturlig undersøgelsespligt til sit område, og at et systematisk, ædrueligt arbejde på videnskabeligt neutral basis var uomgængeligt.

I efteråret 1945 fandt derefter en række drøftelser sted, som dannede grundlaget for et af Rosenkrantz, Ødum og Noe-Nygaard udarbejdet memorandum af 3. december 1945 vedrørende igangsættelsen af systematiske geologiske undersøgelser i Grønland. Allerede i januar 1946 gav Grønlands Styrelse sin tilslutning til, at man kunne gå i gang. Ledelsen af den ny institution kom herefter til at bestå af de tre forslagsstillere samt Styrelsens direktør, K. Oldendow (fra 1949 Eske Brun). I sommeren 1946 lagde man ud med ialt 24 mand fordelt på Nord-, Syd- og Østgrønland. Af disse var der 8 geologer fra museet og fem studenter. Blandt dem er der grund til at bemærke en lang fyr, der hed Knud Ellitsgaard-Rasmussen.

Såvidt forholdene i Grønland, men hvad med baglandet? Vi må tilbage til København og se på det. Det var forsåvidt et udmærket udgangspunkt at anvende de foran nævnte institutioner som paradigma, men der var en væsentlig forskel på deres og GGUs situation. De var gamle $\mathrm{i}$ gårde og havde bl.a. husly, det havde GGU ikke.

Den embryonale institution hvilede formelt på tre tappe, nemlig Danmarks Geologiske Undersøgelse (DGU), Danmarks Tekniske Højskole (DTH) og Københavns Universitet (KU); men hertil er at sige, at DGU selv var i pladsnød, og at DTH ikke besad et eget geologisk institut, idet professor Rosenkrantz var indlogeret på Mineralogisk Museum. Der var de facto kun en mulighed, nemlig Østervold nr. 7, som jeg bestyrede på universitetets vegne.

Det faldt $\mathrm{i}$ begyndelsen Undervisningsministeriet, der $\mathrm{i}$ forvejen ikke have for meget at rutte med til egne opgaver, uhyre svært at forstå og gå ind for betydelige bygningsarbejder på museets lofter og i dets kældre, når det endvidere skulle st $\emptyset$ tte en betydelig udvidelse af dets medarbejderstab med folk, der ikke umiddelbart kom universitetsarbejdet til gode. Der blev skrevet utallige skrivelser og slidt masser af trapper, der uddeltes og modtoges 'næser', før den første femårsperiode var til ende. Da var imidlertid GGU begyndt 'at gå op for folk', 
og statsministeren (Erik Eriksen) kunne i 1951 betegne GGU-udvalget som værende af 'mere permanent' karakter (en komparativ jeg dog sprogligt må tage afstand fra).

I min første samtale med direktør Oldendow nævnte jeg vor manglende erfaring i grundfjeldsgeologi, og at studieophold $\mathrm{i}$ udlandet for nogle af vore studenter var en nødvendighed. Det blev overhørt eller i hvert fald ikke forstået. Jeg måtte gå en anden vej. Med professor Tom Barth, Oslo som mellemmand lykkedes det at bevæge en af hans tidligere studenter, dr. philos. Hans Ramberg, til at modtage en ansættelse som amanuensis ved Mineralogisk Museum med reelt tjenestested i Grønland for GGU. Det fik vidtrækkende følger for igangsættelsen af karteringen af grundfjeldet. Ramberg havde ideer og kunnen, han sled som et bæst i marken og han leverede rundhåndet impulser til de unge studenter, som han fik betroet vejledningen af. Opdragergerningen fik ikke mindre betydning end selve arbejdet i felten. Dermed var i første omgang et vigtigt skridt taget.

Ikke før GGU var blevet et mere konsolideret organ, lykkedes det at opnå en årlig bevilling til 'supplerende uddannelse' af en lovende dansk geologistuderende med henblik på fremtidigt arbejde i Grønland. For dit vedkommende, Ellitsgaard, blev det til studieophold ved SGU i Stockholm og ved Macaulay Institute i Aberdeen. Så blev du indhentet af skæbnen og måtte opgive at gå videre med din egen videnskabelige fremtid som geokemiker, men Grønland svigtede du ikke - tværtimod. Men inden du forlod primærperioden i grundfjeldsundersøgelserne i Vestgrønland, fik du guldmedalje for din afhandling om de lavmetamorfe øer nord for Egedesminde (Meddelelser om Grønland 136(6), 1954).

Det er nu slet ikke så lidt, der kan lade sig gøre, hvis man prøver (gammelt jysk mundheld)

Middelalderen: Valget af dig som leder var for mig ligetil; du var den modneste og mest ansvarsbevidste af de mulige kandidater, og du havde virkelig levet dig ind i opgaven i Grønland. På din egen krop havde du oplevet arbejdsvilkårene og ekspeditionslivet under overvintring i Peary Land i 1949-50 og forbandt dermed fortid og nutid.

Jeg var efterhånden ved at forløfte mig på det, jeg havde påtaget mig. I mine første tolv professorår underviste jeg $\mathrm{i}$ de fleste af fagets discipliner både ved Københavns Universitet og Den Polytekniske Læreanstalt, og før krigens udbrud var jeg gået $i$ gang med den geologiske kortlægning af Færøerne på Danmarks Geologiske Undersøgelses vegne. Da så Ramberg for godt flyttede til Amerika i 1951, stod jeg tilbage med ansvaret for prækambriet i Grønland også!

I denne for mig kritiske situation var det, at du uden mange dikkedarer stilfærdigt gled ind og begyndte at overtage større og større andele af mine grønlandske byrder. Det er jeg dig uendelig taknemmelig for.

Gennem din indtræden i 1956 som daglig leder af det, der nu officielt hed GGU, nærmede vi os formaliserede tilstande, selvom det holdt hårdt at komme videre.

Når jeg i dag tænker på dagliglivet i den sidste tid af vort samliv på Østervold 7, hvor vi var nær ved at sidde lårene af hinanden, og vi havde måttet pakke en museumssal sammen for at skaffe jer en tegnestue, gør jeg det med glæde, fordi man under de indeklemte pladsforhold alligevel præsterede noget positivt. GGU-folk og universitetsfolk gik op og ned ad hinanden, sad ofte flere af begge slags i samme rum og arbejdede tit med beslægtede opgaver, der 
greb ind $i$ hinanden på en frugtbar måde. Teori og praksis blev sammenvævet. Vi var tvunget til at vise hensyn i stort og småt, og det blev klart dit mål at bidrage så meget som muligt til at dette lykkedes.

Det var efterhånden blevet GGU-udvalgets ønske helt at overlade arbejdet i GGU til de geologer, der gradvist var blevet knyttet fast til institutionen, med dig som leder. Da dette bedst ville kunne lade sig gøre, hvis institutionen erhvervede egen status som direktorat under Ministeriet for Grønland, stillede vi forslag om dette. I 1958 leverede vi udkast til lov for GGU. Det blev forsinket i ministeriet, men kom dog til at indgå som arbejdsdokument for den i 1960 nedsatte minelovskommission, sammen med vort forslag til minelov for Grønland. Ikke før end i 1965 vedtog Folketinget Lov om Grønlands Geologiske Undersøgelse og Lov om mineralske råstoffer i Grønland. De to love var kædet sammen på den måde, at GGU fik tillagt funktioner i forbindelse med administrationen af loven om mineralske råstoffer. GGU-loven forudsatte endvidere oprettelsen af et selvstændigt direktorat. Myndighederne forhastede sig ikke. I 1966 blev du endelig udnævnt til direktør efter i 10 år at have haft den faktiske ledelse på usikre vilkår. Udvalget opløste herefter sig selv.

Nyere tid: Kort efter at du var blevet direktør for et selvstændigt direktorat, lysnede endelig også boligforholdene. Den årelange, opslidende debat om anvendelse af den af DTH forladte bygning på Østervold 10 løstes af departementschef A. Vöhtz i Undervisningsministeriet til vor fordel, idet bygningen blev tilkendt geologerne, inklusive GGU! En af GGUs styrkesider er efter mit sk $\varnothing n$ den fortsat nære bygningsmæssige forbindelse med universitetets institutter.

Hvordan bar du dig egentlig ad med at klare ærterne? Med en egen stilfærdig myndighed fordelte du dit områdes opgaver mellem dine medarbejdere, således at ansvar og indsigt hele tiden fulgtes ad. En arbejdsmåde som desværre ikke langere lader sig praktisere ved universiteterne. Du stillede logistisk hjælp til rådighed også for universitetsinstitutternes projekter i Grønland, og du søgte samarbejde med universiteter og lærdomssæder ud over Europa, hvor unge geologer med en anden oplaring end vor hjemlige bidrog til at udvide dine egne medarbejderes horisont.

I løbet af 25 år fra vor famlende begyndelse i 1946 havde du opnået et imponerende resultat. Du havde fået en geologisk undersøgelse sat på skinner. Det gjorde du bl.a. ved supplerende bemanding fra England, Holland og andre steder, når landet ikke selv kunne følge med i produktionen af egnede kandidater. Det, du opnåede, var en sådan standard for en undersøgelse, at det med rette vakte opsigt rundt omkring. Personligt har jeg hørt dens renommé prise i tre verdensdele. Man kan undre sig over, at det skulle vare så længe, inden hjemlige myndigheder uden for geologernes egen kreds fik øjnene op for det klenodie, du har rakt dem i form af GGU. Det smukkeste og værdigste udtryk for det, der præsteredes i dine år, er uden tvivl Geology of Greenland. Mig glædede det især at finde grundfjeldet behandlet på c. 100 sider; det var det felt, hvor vi havde været længst tilbage $\mathrm{i}$ begyndelsen.

Qualis dominus, talis est servus (Petronius)

Nyeste tid: Nu har du overladt din institution til nye kræfter. Set fra mit hjørne af tilværelsen fører Martin Ghisler GGU videre på en måde, du er vel tjent med.

Det bind, der i dag hilser dig på 40-års dagen for GGUs begyndelse, er ikke mindre al- 
sidigt end Geology of Greenland var det, selvom det fremtræder som en arbejdsrapport, altså ' $i$ arbejdst $ø j e t$ '. Jeg noterer med tilfredshed stigningen $i$ omfanget af anvendt geofysik og indførelsen af remote sensing som tegn på, at I følger med tiden. Man aner ekkoet fra den store geologiske indsats i det allernordligste Grønland i flere af artiklerne, og man følger med interesse jeres aktive deltagelse i planlægningen af mulig vandkraftudnyttelse og spejden efter oliemuligheder på land. Hvis jeg igen må pege på en ting, som i særlig grad appellerer til mig, er det historien om de nedre tertiære plateaubasalter i Østgrønland, pendenten til den færøske sekvens, som for nylig er blevet aktuelt belyst ved to dybe boringer.

Kære Ellitsgaard, med tilfredshed kan du se tilbage på velgjort gerning såvel i Grønlands som i dit eget lands tjeneste. Til lykke med at have stået distancen og til lykke med den anerkendelse, der følger på de efterfølgende sider fra dine gamle medarbejdere.

Arne Noe-Nygaard

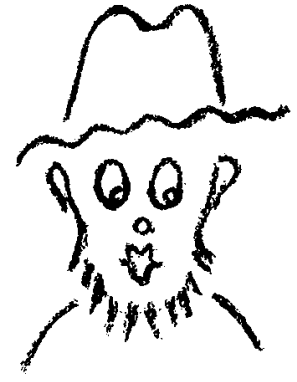

K. Ellitsgaard-Rasmussen

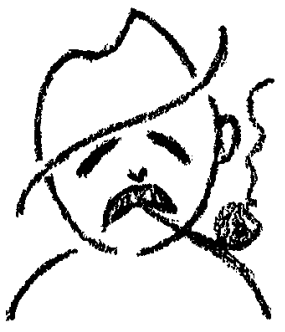

A. Noe-Nygaard

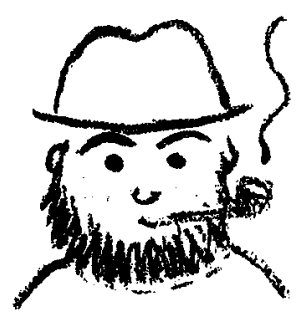

H. Ramberg 